\title{
Medicine of Words: Purgative Reading in Richard Rolle's Meditations on the Passion
}

\author{
Daniel McCann
}

\author{
Dr Daniel McCann (Daniel.mccann@ell.oc.ac.uk) is a Leverhulme Early Career Fellow \\ at St Anne's College, Oxford.
}

\begin{abstract}
This article explores the idea of therapeutic reading during the later Middle Ages in relation to Richard Rolle's Meditation on the Passion. Focusing on Rolle and his therapeutic conception of reading as a medicine of words, the article begins by noting the great frequency with which medical terms, images, and phrases occur in his vernacular writings. It highlights how $\sin$ is understood by Rolle as an affective poison, one that must be removed from the soul through intense affective states that are held to be purgative. The article then moves to consider how exactly medieval texts evoke affective states. It notes the importance of vivid images and their ability to elicit emotive responses, but then turns to medieval texts on grammar and the art of poetry for new ways of understanding precisely how words can evoke the passions of the soul. The article then offers a close reading of Rolle's Meditation on the Passion in light of these grammatical texts, and demonstrates how it functions as a medicine of words - as a texts that works to purge the soul of sin through intense affect states.
\end{abstract}

Keywords: Richard Rolle, affectivity, grammar, reading, vernacular theology, medieval medicine

With his customary confidence and colourful language, Richard Rolle (c. 1300-49) commends the virtues of his translation of the Psalms to the nun Margaret Kirkeby, stating that:

In paime is so mekeil fairehede of vnderstandynge and medicyne of words pat pis boke es called garth enclosed, wele enseled, paradys fulle of appelles. Nowe, with halsom lare, druvyd and stormy saules it bringes in tille the clere and peesfulle lyf, now amonestand to forthink synne with teres, now hyghtand ioy. ${ }^{1}$

${ }^{1}$ Rolle, English Psalter in English Writings of Richard Rolle, Hermit of Hampole, ed. by Allen, p. 5 (emphasis mine). Rolle is drawing here from a long tradition on the effects of reading the Psalter. His main sources are Cassiodorus and Peter Lombard. Cassiodorus notes their therapeutic potential, asserting that 'at one time some psalms endowed with health-giving instruction lead louring and stormy spirits into a bright and most peaceful way of life' in Cassiodorus: Explanation of the Psalms, trans. by Walsh, p. 24. Peter Lombard emphasizes their penitential function, dividing the Psalter 'into three groups of fifty, buy which are signified the three conditions of the Christian religions. The first is the condition of penitence; the second of justice; the third, that of praise of eternal life' (p. 107). Rolle makes an identical point, stating that 'pis boke es distynged in thris fyfty psalmes in pe whilke iij states of Cristens mans religioun ere signyfyed; pe first in penaunce, pe toper in rightwisenes, pe thrid in lovynge of endeles lyf' (p. 6). More broadly influential is the Glossa Ordinaria on the Parable of the Good Samaritan, as it specifically combines the ideas penitential purgation with and the treatment of the soul. Interestingly, the Lollard Interpolated Psalter differs in slight ways from Rolle's original, adding some additional detail that works to specify further the textual treatment on offer. The text is 'hele of a seke herte pat coueitep to be helede' (pp. 14-15), and is full 'of medicinale wordes' (pp. 19-20) designed to aid those 'pat 
The Psalms are multipurpose and multimodal, able to evoke contrasting and intense affective states as and when required. Yet there is more going on here than empty flourish or indirect self-praise. Rolle aims to instruct and advise the nun Margaret - herself newly turned to the contemplative life - but he sets out this aim in a specific way, parsing pedagogy in the language of medicine. Such a choice of language is part of Rolle's rhetorical skills and abilities as a writer. But if we view the deliberate use of medical language only as superficial ornament we do a disservice to the writer, the text itself, and the literary and religious culture from which it and similar texts emerge. Form and function interconnect here in a concise and significant way, offering a clear statement of the text's functional self-presentation. This 'medicyne of words' is a statement of purpose as much as a display of compositional and creative skill. Rolle is not offering an unthinking translation of the Psalter prologues made by Cassiodorus (d. 585) and Peter Lombard (d. 1160). His choice of language is deliberately both metaphorical and literal. For him the Psalms are actually therapeutic, they can in fact operate as a way of treating the soul. It must be remembered that for Rolle, as for many throughout the medieval period, the concept of health overlapped with the concept of salvation: the Latin word salus has a dual meaning. ${ }^{2}$ Such a medicinal conception of reading is not, however, unique to Rolle. It possesses a long and distinguished history in medieval medical and monastic culture - a history that would have been familiar to Rolle despite his monastic detractors. ${ }^{3}$

The act of reading - lectio - was understood by medieval medicine as having a dual therapeutic potential. Initially it constitutes a form of physical exercise for the lungs and breath that can offer a cure for indigestion. It was termed clara lectio - reading aloud - and was recommended by Aurelius Cornelius Celsus (c. AD 50) in his De Medicina because it has specific impacts upon the body. ${ }^{4}$ Indeed, as Leclercq notes, physicians 'of ancient times used to recommend reading to their patients as a physical exercise on an equal level with walking, running, or ball-playing'. 5 Such an understanding continued throughout Antiquity and into the Middle Ages, and was a common recommendation in monastic circles. ${ }^{6}$ Reading also possesses an extended therapeutic potential beyond strictly physical exercise. It can also promote health through its ability to evoke and manipulate the affective states or passions of the soul. ${ }^{7}$

languisshep in uerey penaunce' (pp. 15-16), in Two Revisions of Rolle's English Psalter Commentary and the Related Canticles, ed. by Hudson, I. Many thanks are owed to Professor Vincent Gillespie, Professor Denis Renevey, Professor John C. Hirsh, and Sr Maggie Ross, who all commented on an earlier version of this paper. Also, thanks are due to the anonymous readers of this article for their suggestions for improvement. I would also like to thank The Leverhulme Trust for funding my research.

${ }^{2}$ As Victor White, notes, salus 'is not just salvation in the sense of pie-in-the-sky: it must be given its full significance of "health", "weal", "well-being", "total-integration"” (Holy Teaching, p. 10).

${ }^{3}$ As John A. Alford notes in 'Rolle's English Psalter and Lectio Divina', Rolle's Psalter translation is an attempt to encapsulate the whole process of lectio divina, to offer Margaret a specific "walk-through" example: it works to lead its readers 'by the design of its translation and exposition toward a meditative form of reading' (p. 59). He makes the convincing argument that Rolle is deeply influenced by monastic reading practices: 'Rolle's translation and commentary are designed to encourage the specific methods of lectio divina. As Margaret enters this enclosed garden, teeming with the fruits of God's word, she is actually led by the shape of the work itself to 'devour them by reading', to 'chew the cud upon them by frequent recollection', to 'lay them up in memory as a most valuable treasure' (p. 52).

${ }^{4}$ Celsus, De Medicina, ed. and trans. by Spencer, p. 46.

${ }^{5}$ Leclercq, The Love of Learning and the Desire for God, p. 15.

${ }^{6}$ Leclercq, The Love of Learning and the Desire for God, pp. 16-20; see also Stock, 'Healing Meditation, and the History of Reading' and 'Minds, Bodies, Readers'.

7 Olson, Recreation in the Later Middle Ages, pp. 40-55, 109-115; and, later, in his 'The Profits of Pleasure', pp. 275-90. 
Affectivity itself falls under the medical category of the res non-naturales - or the nonnatural things. These are six environmental and personal factors that, when meticulously regulated, keep the humours of the body in balance, thereby ensuring good health. They are air and the environment, eating and drinking, exercise and baths, sleep, coitus, and the passions of the soul. ${ }^{8}$ The sixth non-natural, the emotions or passions of the soul, is the most relevant one here. Intense affective states operate, therefore, upon a therapeutic spectrum, and the ability of reading to manipulate those affective states constitutes its broader medical potential. Reading can be considered as a cathartic act. This technical philosophical term is derived from Plato, and denotes a process of emotional cleansing initiated and completed by sufficiently skillful poetic or rhetorical works. It possesses a strongly therapeutic aspect, a fact reflected in its Latin translation. In Calcidius's widely influential version of Plato's Timaeus, written around 300, catharsis is consistently rendered as purgatio. ${ }^{9}$ Thus, it is a term that touches upon medicine, theology, and poetic throughout the Classical and medieval periods. The understanding of catharsis is made most explicit and indeed augmented through Averroes's translation (c.1126) of the Poetics, which expands the emotive potential of catharsis. ${ }^{10}$ There is, however, no compelling evidence that this broader understanding of catharsis was widely held outside of very specific academic circles. Nevertheless, this ability of reading to evoke affective states for therapeutic purposes is widely accepted over the period, and is not limited to secular poetic or rhetorical works.

The monastic lectio divina - 'divine reading' - is one of the most influential forms of reading practice, and it places great emphasis upon the careful manipulation of affective states: the "lectio divina, which begins with grammar, terminates in compunction, in desire of heaven'. ${ }^{11}$ It is a fourfold process (lectio, meditatio, oratio, contemplatio) of intense psychological and cognitive engagement, and involves the body as much as the mind. The second stage of the lectio divina is called meditatio - a word that possesses rich and varied meanings, some which apply equally to physical exercise as well as meditation itself. ${ }^{12}$ The first two stages of this practice are often referred to as ruminatio - 'rumination': a word that not only involves the physical aspects of mastication and ingestion, but by extension the idea of digestion as well. ${ }^{13}$ As diet is one of the res non-naturales, there is a medical significance implicit within this monastic understanding of reading. Augustine (d. 430) makes this more explicit:

Our Lord and God takes care of and heals every ailment of the soul, and so he produced many medicines from the holy scriptures (which you could call the shelves of his pharmacy or drugstore) when the divine readings were being read [...]. There have been many things read, both important and necessary. They are all like that, of course, and yet some things are hidden more thoroughly in the scriptures in order to stretch and test the students, while others are set there openly and ready to hand for the immediate treatment of patients. ${ }^{14}$

${ }^{8}$ Horden, 'Religion as Medicine: Music in Medieval Hospitals', p. 143.

${ }^{9}$ Cohen-Hanegbi, Accidents of the Soul, p. 28.

${ }^{10}$ Vincent Gillespie, 'From the Twelfth Century to $c$. 1450', p. 173

${ }^{11}$ Leclercq, The Love of Learning and the Desire for God, p. 72.

${ }^{12}$ Leclercq, The Love of Learning and the Desire for God, p. 16.

${ }^{13}$ Leclercq, The Love of Learning and the Desire for God, p. 73.

${ }^{14}$ Augustine, Sermo XXXII. In Psalmum CXLII. De Golia et David ac de contemptu mundi, in Patrologia cursus completus series latina, ed. by Migne and others, vol. 38, col. 197: 'Deus et dominus noster curans et sanans omnem animae languorem, multa medicamenta protulit de scripturis sanctis, velut de quibusdam armariis suis, cum lectiones divinae legerentur [...]. Multa lecta sunt, et magna, et necessaria; quanquam ita sint omnia: sed tamen alia secretius in scripturis absconduntur, ut quaerentes exerceant; alia vero in promptu et in manfestatione ponuntur, ut desiderantes curent.' In the quotations from Augustine, I use the Latin transcriptions 
The monastic lectio has a definite medical potential and use, capable of treating a variety of patients in the most personally tailored of ways. The equation of reading with the ingestion of pharmaceuticals is an integral part of Augustine's broader conception of Christ as a physician - the Christus Medicus. This topos has very rich history in patristic writings, but is ultimately derived from Christ's own presentation of himself as a physician in Matthew 9. 12. From the second century onwards the Christus Medicus image is used more frequently, occurring in Ignatius of Antioch (d. 107), Epistula ad Ephesios, 7.2.20; Clement of Alexandria (d. 215), Paedagogus, 1; Origen (d. 253), Contra Celsum, 3.62; Tertullian (c. 155240), Adversus Marcionem 3. 17, and Cyprian (d. 258), De opere et eleemosynis, $1 .{ }^{15}$ Yet it is in the works of Augustine that the topos reaches maturity. In his Enarratio in Psalmos, Christ is the ultimate medical doctor and surgeon (Ps. 40; 51; 67), who cures through an explicitly textual medicine - the verbi medicina, or medicine of the word (Ps. 93.7). This is a complex allusion to both Christ as the Word, and to the Scriptures themselves, one that is given further elaboration in the form of the fomenta verborum, or poultice of words:

Your conscience had gathered up evil humours, with boils it had swollen, it was torturing you, it suffered you not to rest: the Physician applies the fomentations of words, and sometimes He lances it, $\mathrm{He}$ applies the surgeon's knife by the chastisement of tribulation: do thou acknowledge the Physician's hand, confess thou, let every evil humour go forth and flow away in confession. ${ }^{16}$

While the sacrament of confession is mentioned here as another form of treatment, it is the medicine of words that is the option of first resort. The phrase fomenta verborum alludes as much to the actual person of Christ - who is Himself the Divine Word - as it does to "the scriptures in general, or even to the homilies spoken aloud in the churches of the day'. ${ }^{17}$ Reading the Psalms, that constant of monastic life, unlocks that textual medicine in the most direct of ways. Once again, affective reactions are key:

What man does live without affections? And do ye suppose, brethren, that they who fear God, worship God, love God, have not any affections? Will you indeed suppose and dare to suppose, that painting, the theatre, hunting, hawking, fishing, engage the affections, and the meditation on God does not engage certain interior affections of its own? ${ }^{18}$

Reading, if done correctly, will generate affective states. Without them the textual medicine will not be accessible, as true reading has not actually taken place. The poultice of words is the product of the reader's affective reactions to the words of the Bible. Such a medicinal understanding of the operation of the scriptures is central to Rolle's own 'medicyne of words'.

from Shelley Annette Reid, 'The First Dispensation of Christ Is Medicinal: Augustine and Roman Medical Culture', p. 206.

15 For an overview of this topos see Rudolph Arbesmann's 'The Concept of "Christus Medicus" in St. Augustine', Traditio, 10 (1954), 1-28, and Reid, The First Dispensation of Christ is Medicinal.

${ }^{16}$ Augustine, Enarratio in Psalmos, 66.7, Patrologia cursus completus series latina, ed. by Jacques-Paul Migne and others, vol. 36, col. 809: 'Conscientia tua saniem collegerat, apostema tumuerat, cruciabat te, requiescere non sinebat: adhibet medicus fomenta verborum, et aliquando secat; adhibet medicinale ferrum in correptione tribulationis: tu agnosce medici manum; confitere, exeat in confessione et defluat omnis sanies.' The translation is by J. E. Tweed in Nicene and Post-Nicene Fathers, First Series, Vol. 8: St. Augustine: Expositions on the Psalms, ed. by Schaff, p. 284.

${ }^{17}$ Reid, The First Dispensation of Christ is Medicinal, p. 216.

18 Augustine, Enarratio in Psalmos, 76.14, Patrologia cursus completus series latina, ed. by Migne and others, vol. 36, col. 978: 'Quis vivit sine affectionibus? Et putatis, fratres, quia qui Deum timent, Deum colunt, Deum diligunt, nullas habent affectiones? Vere, hoc putabis, et putare audebis, quod affectiones habeat tabula, theatrum, venatio, aucupium, piscatus, et non habeant opera Dei et non habeat meditatio Dei interiores affectiones quasdam suas?' The translation is by J. E. Tweed in Nicene and Post-Nicene Fathers, First Series, Vol. 8: St. Augustine: Expositions on the Psalms, ed. by Schaff, p. 364. 
His presentation of the Psalms as therapeutic is derived in part from his Patristic and monastic forebears. When he asserts that the Psalms enable the reader to 'forthink synne with teres, now hyghtand ioy', he is highlighting that their dual affective function enjoins 'both the penitential and the faithfully amatory'. ${ }^{19}$ It is through these passions that Christ, the ultimate medical doctor, can treat the soul - passions that Rolle will attempt to evoke through the complex style of his writings. Like Augustine, he too makes extensive use of the medical metaphor. While Rolle was certainly not a medical doctor, and his energies and efforts where directed elsewhere, the language of medicine is a subtle but considered presence throughout many of his vernacular writings. Terms of medical diagnosis, of aetiology and treatment, occur with more than accidental frequency, and function at the very least as imaginative analogies for the spiritual states and practices he describes. Christ is frequently represented as the 'hevenelyche leche' ${ }^{20}$ and creator of 'sorrowyng medicyne' ${ }^{21}$ whose very name means 'health' - 'sothely Ihesu es als mekyll to bemen, als saueoure or helefull': ${ }^{22}$

Yit, swet Jhesu, in pe is al sovereyne medicyne, and I Lord, am al sek in synnes; perefor, swet Jhesu, tak me to pe, and set me undyr py cure. ${ }^{23}$

Rolle carefully establishes a compelling contrast here between Christ as the source and locus of all health, and the narrator/reader as the source of all disease and sin. A similar figuration occurs elsewhere: 'Be pou leche vnto pis woundyde. If pou come, I am hale; I fele me noghte seke bot langwyssande for pi lufe. ${ }^{24}$ Both instances generate a specific relational context for the reader to inhabit: Christ is source of medical treatment, and the reader must submit to his care. The use of medical metaphor in these examples strongly recalls that idea of Christ as the Christus Medicus. However Rolle goes further, and presents proximity to Christ as that which equates with health. Christ is the Divine Physician, but it is access to him that enables his medical care to be effective. Such a medicinal understanding is achieved though particular textual means - the lectio divina: 'Here, swete Jhesu, I besech pe pat pese woundes be my meditacion nyght and day, for in py woundes is hool medicyne for euche desasise of soule'. ${ }^{25}$ It is through the lectio divina that the reader can engage with the Divine Physician directly: affective mediation is the key to this form of treatment. The emphasis on affective response as a way of treating the soul recurs over the course of Rolle's vernacular writings. In his Incendium Amoris, quoted here from the Middle English translation made by Carmelite Richard Misyn (d. 1462), love itself becomes a medicinal drink; love is the 'holy letwary', as 'lufe bryngis vs gostly medcyn'. ${ }^{26}$ Once again, affective states are key to the medicine of words.

These examples are far from the only instances of medical metaphor in Rolle. Yet the other examples bear witness to one of the signature features of Rolle's style as a writer: his tendency to combine in a single paragraph, sometimes a single sentence, a range of metaphors in an attempt rhetorically to engender specific affective states within the reader. For instance, the concept of sin in his vernacular works is often inflected with medical ideas of toxicity and purgative extraction. In the Ego Dormio it is a toxic poison, 'venemus synne', that is 'bitterer pan pe gall, sowrar pan pe atter'. ${ }^{27}$ The Oelum Effusum likewise stresses its poisonous nature

\footnotetext{
${ }^{19}$ Hanna, 'Rolle and Related Works', p. 24.

${ }^{20}$ Rolle, Meditations on the Passion A, ed. by Allen, p. 27, 11. 266.

${ }^{21}$ Rolle, 'A Salutation to Jesus', ed. by Allen, p. 48, 1. 1.

${ }^{22}$ Rolle, Oleum Effusum, ed. by Hanna, p. 3, 11. 4-5.

${ }^{23}$ Rolle, Meditations on the Passion B, ed. by Allen, p. 30, 11. 85-87.

${ }^{24}$ Rolle, Oleum Effusum, ed. by Hanna, p. 5, 11. 38-40.

${ }^{25}$ Rolle, Meditations on the Passion A, ed. by Allen, p. 34, 11. 241-42.

${ }^{26}$ Rolle, Incendium Amoris, ed. by Harvey, p. 96, 1. 17; p. 97, 11. 16-17.

${ }^{27}$ Rolle, Ego Dormio, ed. by Allen, p. 64, 11.94 and 102.
} 
but also provides an analysis of what sin principally is. Referring specifically to the healing power of the name of Jesus, he asserts that:

Sothely nathynge slokynns sa fell flawmes, dystroyes ill thoghtes, puttes owte venemous affeccyons, does awaye coryous and vayne ocupacyons fra vs. This name Ihesu lelely haldyn in mynde drawes by pe rote vyces, settys vertus, insawes charytee, inzettis sauoire of heuenly thynges. ${ }^{28}$

Sin is an emotional toxin, a poison generated by pernicious and purulent affective states. Yet medical language is a greater feature of this passage than is initially apparent. The word 'rote' can have more than agricultural and botanical connotations during the medieval period, and ranges often into medical contexts. In addition to having an anatomical meaning as the basal portion of an aposteme or bodily organ, ${ }^{29}$ 'rote' is often used in medical texts to stipulate an accepted point of knowledge or as part of formulas of diagnosis: ${ }^{30}$ the doctor must work to determine the 'root cause', or radix, of a specific malady. ${ }^{31}$ The 'root cause' of the soul's sickness is, therefore, sin - a poisonous affective state. Both the agricultural and medical senses of the word complement each other in the passage, and work to ensure that the reader must perform further interpretative and associative work. The combination of these meanings operates in a manner similar to the catena aspect of the lectio divina: words ruminated upon in one passage allude to and recall other words and other passages, their meanings fusing together in a 'chain' of signification. ${ }^{32}$ The reader, ruminating on them, moves mentally into a series of potentially unexpected and even shocking associations. A similar effect occurs in his Incendium Amoris. Directing his comments in this text to an audience of professed religious, Rolle stipulates that those who think themselves saved and better than their fellow creatures are, in fact, deep in sin as 'couetyes, pe rote of synnes, is nozt drawne owte'. ${ }^{33}$ All the various senses of the word 'rote' can apply here, and work to endow the passage with a sense of natural agricultural labour, and a sense of medical necessity. Urgent treatment is required, but it is a relevantly simple one: a burning desire for God so strong that it 'pourgis pame fro all degres of synne'. ${ }^{34}$

For Rolle it is vital that 'syn is pourgyd' -- an emotionally cleansing process with mystical, medical, and even poetic connotations. ${ }^{35}$ Aside from being the first stage of the threefold contemplative way of purgatio, illuminatio, and unio, purgation is also a mainstay of medieval medical treatment used to address humoral imbalances. In his epistle The Commandment, Rolle asserts that the reader must 'purge pi soule of al filth, as clene as pe gold pat is proued in pe fourneys'. ${ }^{36}$ Once again the sense of medical purgation is fused onto the more immediate sense of the refinement of precious metals by intense heat. The result is a metaphorical construction that lends intensity to the idea of removing sin: it is neither a gentle nor easy process, and requires some degree of concentrated force. From here Rolle specifies how such purgation is to be accomplished. The soul can 'be purget progh prayers and penaunce and good thoghtes in God'. ${ }^{37}$ A whole range of activities is alluded to here, from penitential states, to meditative compassion, to devotional longing and prayer. Specific forms

${ }^{28}$ Rolle, Oleum Effusum, ed. by Hanna, p. 5, 11. 59-63.

${ }^{29}$ Lanfrank, Science of Cirurgie, ed. by Von Fleischhacker, p. 216, 1. 17.

${ }^{30}$ Guy de Chauliac, The Middle English Translation of Guy de Chauliac's Anatomy, ed. by Wallner, p. 56, 11. $22-23$.

${ }^{31}$ Guy de Cauliac, The Cyrurgie of de Chauliac, ed. by Ogden, p. 115, 1. 7.

${ }^{32}$ Carruthers, Book of Memory, p. 44.

${ }^{33}$ Rolle, Incendium Amoris, ed. by Harvey, p. 5, 1. 7.

${ }^{34}$ Rolle, Incendium Amoris, ed. by Harvey, p. 10, 11. 18-19.

${ }^{35}$ Rolle, Incendium Amoris, ed. by Harvey, p. 66, 1. 40.

${ }^{36}$ Rolle, The Commandment, ed. by Ogilvie-Thomson, p. 38, 11. 186-87.

${ }^{37}$ Rolle, The Commandment, ed. by Ogilvie-Thomson, p. 37, 11. 124-25. 
of religious practice function medically, working to purge the soul of its affective poison through intense affective manipulation. Holy words in particular, whether spoken in penance and prayer or meditatively reflected upon, form an important part of this. For Rolle, the health of the soul can thus be achieved through textual means, by 'lukyng in haly bukes', books that provoke specific affective states to purge the soul of its poison. ${ }^{38}$ However, it is not just Rolle's translated Psalter that can evoke purgative passions. Many of his writings seek to perform such a medicinal function through their stylistic construction, carefully and deliberately using language as a means of evoking and sustaining strong affective states. In this respect Rolle's authorial practice is consistent with his cultural context, as the idea of such affective purgation possesses a long pastoral history. ${ }^{39}$

\section{Purgative Reading}

Whether catechetical or contemplative, any 'medicine of words' will attempt to treat the soul in this way: to purge it by evoking intense penitential states. It is an idea that Langland plays with in the feast of Conscience:

Conscience called after mete, and thanne cam Scripture

And served hem thus soone of sondry metes manye --

Of Austyn, of Ambrose, of alle the foure Evangelistes [...]

Conscience ful curteisly tho commaunded Scripture

Bifore Pacience breed to brynge and me that was his mete.

He sette a sour loof toforn us and seide, 'Agite penitenciam'. ${ }^{40}$

Words form the food on offer here, the 'sour loof' being nothing other than an injunction to penance, a quotation from Scripture served by Scripture to perform a specific action. Sourness is one of the key qualities of many purgatives during the period, and so its function in this context is a signal that the textual feast put before Will and Patience has a therapeutic aspect: the 'sour loof' of penance is a textually mediated purgative. ${ }^{41}$ The next Passus elaborates upon this, when Patience presents penance as the ultimate medical procedure and purgative cure: confession is 'surgiens for dedly synne', and 'satisfaccion seketh out the roote, and bothe sleeth and voideth'. ${ }^{2}$ Operative within the presentation of Scripture's 'sour loof' is an understanding of words, specifically Holy Words, as carrying out an emotionally purgative function - purifying the soul by evoking sorrow for $\sin$ — when ruminated upon. This understanding of the digestive effects of the Scriptures occurs in Rolle's own writings. In his exposition of the Psalms, he notes that when they are ruminated upon they feed the reader a

${ }^{38}$ Rolle, Desyre and Delit, ed. by Allen, p. 58, 1. 36.

39 Penance was often understood during the Middle Ages as a purgative cleansing of the soul predominately affective in character. A particularly detailed rendering can be found in the Twelve Profits of Tribulation, a popular fifteenth-century Middle English translation of the Tractatus de tribulacione wrongly attributed to Rolle. Here the purgation of the soul consists of the medicinal drink of tribulation and the phlebotomy of confession: 'For as the body is purged by medicinalle drinkis of euell humoris, ryght so is the soule made clene by tribulacions sent from the souereyne leche oure lord god of veyne affeccions and euell maners. [...] the secund purgacion of mannys body for euel humoris is by crafty blood-lettynge, and that is of two manners, as by openynge of pe veyne, or els by boxynge of ventusynge. Openynge of the veyne is properyd to confession, and boxynge or ventusyng, to tribulacion'. See the Twelve Profits of Tribulation, ed. by Horstmann, p. 394.

${ }^{40}$ Langland, Piers Plowman, ed. by Schmidt, B XIII, 11. 37-49.

${ }^{41}$ Carruthers, The Experience of Beauty in the Middle Ages, p. 104.

${ }^{42}$ Langland, Piers Plowman, B XIV, 1. 88; XIV, 1. 94. 
'brede of teris'. ${ }^{43}$ They constitute an affective food: 'teris was til me brede day \& nyght [...] that is, anguys and tribulacioun was not til me bitternes. bot brede, that is, delite and fode' ${ }^{44}$ Reading in this manner is highly emotive, but also highly physical as it results in the further digestive process of eructation or belching: "my hert riftid goed word [...] that is, my thoght withinen, delitid in god and fild, riftid as ful of goed worde. that is, louynge til god' ${ }^{45}$ After reading the scriptures, masticating and ingesting their bitter and sorrowful content, the reader will belch forth good words. For Rolle, meditative reading is understood in the most physical of ways, constituting a form of affective ingestion that results in an intensive affective digestion and response. Such affective stimulation through reading is peculiar to poetic, emerging from what Classical rhetoricians call the enargeia of a text. ${ }^{46}$ Medieval poetic theory is deeply concerned with processes of imaginative recreation/re-presentation, and the psychological and affective impact of vivid images. The category of vividness is given some considerable critical attention, understood via the terms ekphrasis and enargeia:

Literary impact is created by the presentation of a phantasia, but can only be adequately generated when presented by those that have a clarity of manifestation (enargeia/declaratio) that is peculiar to themselves and which therefore permits katalepsis or comprehensio on the part of the audience. This imaginative vividness, this gifted imagination, endues the poet with the power of communication that generates strong reactions in the mind of the reader or hearer and allows the audience to become co-creators of the phantasm generated in the imagination. ${ }^{47}$

Poetic images are, when heard or read, memory phantasms - not images seen by the senses directly but rather verbal simulations recreated imaginatively through the work of memory. ${ }^{48}$ Every poetic image is in this way a composite of both simulated sense data and the immediate affective reaction to that sense data - a 'feeling-toned' combination of sense and intention. ${ }^{49}$ In and of itself any phantasm will move the soul in the most technical of ways as human psychology cannot behave otherwise. Each verbally mediated phantasm will stimulate not simply the senses, but also the affections as well through the simulation of sense data. Descriptions of delicious food and foul smells are naturally geared towards certain senses via the enargeia of their presentations, but they will also evoke feelings of desire or aversion as well by virtue of the mechanisms of human psychological response. The poetic image thus has an inbuilt emotive potential; however, the conveyance of that image through language is equally important. The art of poetic composition is thus as important as the mechanisms of human psychology for understanding how texts can evoke affective states. During the Middle Ages, the art of grammar (ars grammatica) offered training not simply in language, but also in composition and interpretation. As Jesse Gellrich notes, grammatical study shifts during the high Middle Ages to 'an interest in how language signified, rather than in what it signified'. ${ }^{50}$ The connection between language and affect is one of its key themes. Initially, elementary grammar texts such as Ars Minor and Ars Maior of Donatus (fl. fourth century) specify one part of speech as signifying emotion:

\footnotetext{
${ }^{43}$ Rolle, Psalter, ed. by Bramley, Ps. 79, p. 294.

${ }^{44}$ Rolle, Psalter, ed. by Bramley, Ps. 41, pp. 153-54.

${ }^{45}$ Rolle, Psalter, ed. by Bramley, Ps. 44, p. 163.

${ }^{46}$ Gillespie, 'The Senses in Literature', p. 154.

${ }^{47}$ Gillespie, 'The Songs of the Threshold' (forthcoming).

${ }^{48}$ Carruthers, The Book of Memory, pp. 59-60.

${ }^{49}$ Carruthers, The Book of Memory, p. 57.

${ }^{50}$ Gellrich, The Idea of the Book in the Middle Ages, p. 105.
} 
The interjection is a part of speech thrown in between the other parts of speech to express the affects of the soul; either of someone who fears, like $e i$; or of someone who wishes, like $o$; or of someone in pain, like heu; or of someone merry, like evax. ${ }^{51}$

Similar ideas are expressed in a more theological context by Hugh of St Victor (d. 1141):

The interjection is a part of speech which, thrown between the other parts of speech, only expresses the affections of the soul with unelaborated sound which seems to arise from nature rather than from culture therefore it is found to be common among almost all people. ${ }^{52}$

These parts of speech are raw and powerful eruptions of affect, almost devoid of rationality. In theology they have a particular use in classifying the degree of sin committed in expressions of immoderate affect. Outbursts of rage and angry denouncement could, when grammatically analysed, be keyed into various categories of sin. The use of such parts of speech carried a danger, as they indicate that within the soul of the speaker the rational had lost out to the affective. ${ }^{53}$ Affect, not concept, had dominated the mind. ${ }^{54}$ More precise and accurate understandings of degrees of sin would have a definite pastoral utility. Yet, beyond its use as a classificatory tool for sin, such parts of speech also appeared in the liturgical responses - Benedicimus Domino, Deo Gratia, Ita missa est, Amen, Hosanna, and Alleluia - were long understood as interjections of prayer or jubilation. ${ }^{55}$ Though interjections can vary in their use, what they have in common is their mode of signifying. They are technically 'co-signifiers' or syncategoremata, and as such they signify not concrete things or concepts in and of themselves, but rather dispositions towards concrete things or concepts. With the interjection - as early medieval grammar understands it - there is the potential for it to signify as well as to evoke specific affective states.

During the twelfth and thirteenth centuries the focus on the relationship between language and reality intensifies as the reintroduction of Aristotle and the emergence of speculative logic causes seismic shifts in medieval intellectual life. Grammar is no exception. Over the course of the twelfth to fourteenth centuries there gradually emerges a new 'speculative grammar', an approach to the study of languages influenced by scholasticism that includes a strong taste for the approaches of speculative logic. The essential premise of this type of grammatical study is that a direct relationship exists between language and reality; and that a universal grammar could be established 'based on the structure of reality and human thought'. ${ }^{56}$ In effect, speculative grammar studies the connection between language and ontology. The parts of speech mentioned above become recategorized under various 'modes of signifying', and the grammarians who practised this approach become known as the Modiastae. Interjections, as Roger Bacon (d. 1294) notes in his Communia Naturalium, signify 'per modum affectus' -- in the mode of affect rather than concept. ${ }^{57}$ These words stand at the threshold between raw sensory movements of the soul and conceptual apprehension in the rational soul. Their utility in evoking strong affective states is, therefore, considerable so much so that John of Garland (c. 1190-1270) recommends their use in poetic composition:

${ }^{51}$ Donatus, Ars Minor, ed. and trans. by Copeland and Sluiter, p. 93.

${ }^{52}$ Hugh of Saint Victor, 'Le De grammatica de Hugues de Saint Victor', ed. by Leclercq, p. 288, 11. $23-26$. Translation is my own; original reads: 'interiectio est pars orationis quae interiecta aliis partibus orationis animi tantum exprimit affectus voce incondita, quae ex natura magis quam institutione profecta videtur; unde communis fere omnibus gentibus invenitur.'

${ }^{53}$ Irène Rosier-Catach, 'Roger Bacon: Grammar', p. 61.

54 Albertus Magnus, 'Super Mattheum', Alberti Magni Opera Omnia: Cura et studio Instituti Alberti Magni, vol. 21, ed. by Schmidt, p. 134, 11. 29-30; Thomas Aquinas, 'De Malo Quaestiones disputatae de malo', p. 387. For additional remarks on these texts see Kelly, The Mirror of Grammar, p. 139.

55 Kelly, The Mirror of Grammar, p. 137.

${ }^{56}$ Alford, 'The Grammatical Metaphor: A Survey of its Use in the Middle Ages', p. 739.

${ }^{57}$ Roger Bacon, Communia Naturalium, ed. by Steele, p. 110, 11. 25-32. 
Interjections always go first whether in an incomplete sentence or in a complete one. They are used to express a feeling or sorrow or joy or fear or wonder. But feeling is expressed better in an incomplete sentence than in a complete sentence, for incompleteness expresses inexpressible feeling. ${ }^{58}$

Such compositional advice can be seen at work in a range of religious texts that aim to evoke strong feeling. For instance, the thirteenth-century English lyric 'Stabat iuxta Christi Crucem' expresses the sorrows of Mary through careful use of the interjection. In its description of Mary it begins two stanzas with the cries 'Ah, lauedi, pat pu wonges wete / pah pe were wo at unimete', and 'Ah pi kare was ouer-comen / pe pridde dai pi ioie comen'. ${ }^{59}$ The narrator's affective responses to the Virgin in her agonies come first, adding emphasis and urgency to the words that follow. Similar constructions are found in the penitential lyric 'Now Comes the Blast of Winter': 'Ej! ej! phat pis nicht is long / and ich pid pel michel wrong'; and the lyric 'Death's Wither-Clench' begins each refrain with 'wela-wey'. In these texts the interjection opens as an anguished cry for misspent youth and wasted time, one that accentuates the impact of the lines that follow by adding highly personal and emotive force. In the fifteenth century 'Quia Amore Langueo', Mary's reaction to the Passion reaches new heights of intensity, as she exclaims 'Yet prykketh myne hert bat so ny my kynne / Shuld be dysseased, o sone, allasse!'. ${ }^{60}$ While the line does not being with the interjection, it still works to express overwhelming feeling. Yet the placement of the interjection has the added effect of showing how the composed complaint of the Virgin breaks down through an outpouring of emotion, as her speech dissolves under intense pressure into a single, heartfelt, cry. While the use of the interjection here differs from the compositional advice offered above, it nevertheless performs the same function: conveying and evoking affect by signifying per modum affectus.

This manner of signification is, however, not unique to interjections. Through poetic form, with its ability to exploit the supple or elastic power of language, other words can be made to signify in this way. Repetition, meter, alliteration, medial/end rhyme - the whole host of poetic features can all be used to augment the potency of interjections, or to make normal nouns signify in this way. Richard Rolle's 'Song of the Love of Jesus' offers an interesting example:

Lufe es thoght, wyth grete desyre, of a fayre lovyng.

Lufe I lyken til a fyre, pat sloken may na thyng.

Lufe us clenses of oure syn, lufe us bote sall bryng.

Lufe pe keynges hert may wyn, lufe of joy may syng. ${ }^{61}$

The word 'lufe' is possesses a wider range of meanings than the reader may expect. Here it is subject to a series of allusions and metaphorical connections that work to stretch and force the normal referential range of the word beyond its capacity. Initially it is defined as a form of cognition, then likened to fire and a cleansing agent, before being rendered as something that wins the King's heart. The word thus becomes all these things and in so doing becomes none of them. Each sentence is a further twist in the signification of the word, each building upon

58 John of Garland, Parisiana Poetria, ed. and trans. by Lawler, p. 113.

59'Stabat iuxta Christi Crucem', in Religious Lyrics of the Thirteenth Century, ed. by Brown, p. 9, 11. 19$20 ; 11.25-6$.

60 'Thole a Little' and 'Quia Amore Langueo', in Religious Lyrics of the Fourteenth Century, ed. by Brown, 2nd edn, pp. 3, 234. Brown notes the date of the 'Quia Amore Langueo' as the fourteenth century, but the manuscript he uses, Douce 322, has been dated to the fifteenth entury by Mooney: see 'Scribes and Booklets', pp. 207-10.

${ }^{61}$ Rolle, 'Song of the Love of Jesus', ed. by Ogilvie-Thomson, p. 43, 11. 5-8. Rolle's use of the Holy Name is receiving increasing critical attention. See Denis Renevey, "The Name Poured Out": Margins, Illuminations and Miniatures as Evidence for the Practice of Devotions to the Name of Jesus in Late Medieval England', in The Mystical Tradition and the Carthusians, ed. by Hogg. 
the last yet working to erase the initial core meaning. Each imaginative jump moves the signification of the word further beyond its normal field of reference. The use of repetition at the start of each sentence generates a powerful and hypnotic anaphora that deepens this whole effect. Such complex rhythmic layering forces these imaginative renderings into careful interconnection. Through the verse the reader is held in a rhythmic suspension that works to efface the normal meaning of the word and shade it into something else. The overall effect is affective - the word ceases to signify in the mode of concept but instead in the mode of affect, as the word becomes stripped of literal meaning and instead functions to compel the reader to feel love for Christ. ${ }^{62}$ As Rolle notes in his Form of Living, 'lufe es perfeccion of letters': there is a clear link in his mind between affective states and the processes of poetic composition. ${ }^{63}$

A capable writer, Rolle is able to employ the tools and techniques of rhetoric to their utmost both in his Latin and vernacular writings. All his works are the product of careful craft and attention to the various effects of poetic and rhetorical composition. While the exact extent of his education remains unclear, Rolle did receive at last a portion of a university education from Oxford. It is reasonable to assume that he has formal training at least in the trivium if not the quadrivium, and that this informs his own understanding of how words can evoke affective states. ${ }^{64}$ His stylistic abilities and range with Latin prose are clear from the Melos Amoris and the Incendium Amoris, but his vernacular writings also show a similar compositional sophistication. The subject matter determines the stylistic choice. Those vernacular texts that deal with devotion to the name of Jesus, or meditation on the Passion, are contexts befitting only the most elevated — and indeed elevating — language. The lyric 'Ihesu swet, nowe wil I synge' presents itself as a 'songe of loue-langynge' designed to evoke a well of desire in the reader. ${ }^{65}$ Almost every stanza begins with the name of Jesus or Mary, and over the course of the lyric this works assertively to generate an almost hypnotic effect upon the reader. Yet, such constant and predictable repetition of the Holy Name also functions to focus the mind, erasing any potentially distracting conceptual significance of the name and instead allowing it signify per modum affectus. Incantatory and potent, each repetition builds up an affective charge, one that Rolle uses for moments of passionate intensity:

Ihesu, pou soffredest for loue so wo

pat blody stremys yow ran fro;

pi white body was blak and blo,

Our synnes hit made, wailawo. ${ }^{66}$

This description of the Passion begins and ends with words of affective charge. Not only does constantly repeated 'Thesu' energize the line with its reiterated force, but also the stanza ends with an interjection of anguish. Such pairing together in this way forces the reader to move from one outpouring of affect to another in rapid succession, a state carried forward through the meter and use of rhyme in the lyric. In texts such as this one, Melos Amoris, Incendium Amoris, and his lyrics, Rolle displays a keen awareness of how to make language signify per modum affectus, to move 'and lift the reader towards ecstasy' -- with amatory feelings so

${ }^{62}$ Gillespie, 'Mystic's Foot: Rolle and Affectivity', p. 273.

${ }^{63}$ Rolle, Form of Living, ed. by Allen, p. 109, 1. 30.

${ }^{64}$ Hanna is very clear that Rolle is 'well trained in the trivium' as he has 'a suitably diverse form of literary statement that will parallel the diverse situations and subjects of his writing' ('Rolle and Related Works', p. 26). While his knowledge of the quadrivium is less on display, it is nevertheless very likely that Rolle had a keen awareness of the affective potential of language.

${ }^{65}$ Richard Rolle,'Ihesu swet, nowe wil I synge', ed. by Ogilvie-Thomson, p. 50, 1. 2; p. 51 , 1. 4.

${ }^{66}$ Richard Rolle,'Ihesu swet, nowe wil I synge', ed. by Ogilvie-Thomson, p. 52, 11. 57-60. 
intense that they move into jubilant joy. ${ }^{67}$ Yet literature can also be used to evoke other affective states, specifically those purgative penitential passions mentioned earlier. While the Psalms can do both and are as such the pre-eminent medicine of words, other texts serve more specifically delineated remedial functions. ${ }^{68}$ One such 'medicine of words' is his Meditations on the Passion A, a text which aims to stir up and maintain in the reader a purgative fear, sorrow, and pity for the crucified Christ.

\section{'Wexenge Manyfold with Hepynge Sorewys'}

The Meditation is, like Rolle's Psalter, also dedicated to the nun Margaret Kirkeby. ${ }^{69}$ Yet this text is not concerned with rendering liturgical Latin into plain English. ${ }^{70}$ Instead, it seeks to control and augment the reader's affective disposition through the deft use of rhetoric and style; it seeks to purge, not teach. Sorrow and compassion are the dominant affects throughout, and Rolle deploys a range of devices to express and evoke those specific passions. However, while this text has been seen as one of his more mature works, it has also been viewed as somewhat flawed, displaying not artistic command but stylistic excesses. H. E. Allen notes that the overall compositional style of the text is one of 'loose construction' and given over to verbal nouns and frequent repetition, all of which constitute 'the great fault in his style'. ${ }^{71}$ Such an appraisal does not, though, emerge from the context of medieval ideas about poetic composition. This text is an extremely sophisticated example of Rolle's rhetorical 'pyrotechnics', as he makes adept use of the affective potential of rhythmic cadences and alliterative poetry to construct a Middle English version of the 'high-style' of his Latin writings. ${ }^{72}$ While short, it is nevertheless potent, carefully designed to evoke and sustain strong affective states to aid in the purging of the soul. It does this by way of loose constructions, repetitions, interjections, and paratactical and hypotactial constructions, not despite them. Such an agenda is evident from the outset, as the text carefully builds up suspense and vivid detail through an initial prayer to Christ:

Swete Lord Jhesu Cryst, Y thanke pe and I zelde pe graces of pat mychel ferdenesse pat pou haddyst for us, whan pou become so ful of angwysch pat an aungel of hevene cam to confortyn pe, wenne bou swattest blod for angwysche. I preye be, Lord, and byseche be, for pi swete mercy, pat pou be min help in al myn angwysch and my fondynges; and send me, Lord, pe aungel of red and of confort in alle my nedys, bat I myzte turne thorow pat swet owt of al sekenesse of soule into lyf of hele of body. ${ }^{73}$

${ }^{67}$ Hanna, 'Rolle and Related Works', p. 27.

${ }^{68}$ Hanna, 'Rolle and Related Works', p. 24.

${ }^{69}$ The attribution of this text to Rolle is not unproblematic as it was treated differently by both Hortsmann and Allen; however, as other critics have noted, it is nevertheless very much in his style; see Watson, Richard Rolle and the Invention of Authority, p. 239. For a more comprehensive focus on this text and its manuscript contexts, see Madigan, The Passio Domini Theme in the Works of Richard Rolle. This text exists in five manuscripts: Cambridge, University Library, Ll. I.8; Cambridge, University Library, Additional 3042; Oxford, Bodley, e Musaeo 232; Uppsala, University Library, C 494; London, British Library, L Cotton Titus C XIX. The edition used here, Allen's, is based on the first.

${ }^{70}$ Morgan notes that while there are later Latin versions of this text, it is more likely to be a greatly embellished derivative of an Anglo-Norman version. See her 'Versions of The Meditations on the Passion Ascribed to Richard Rolle', pp. 93-103.

${ }^{71}$ Allen, Richard Rolle: English Writings, p. 131.

${ }^{72}$ Hanna, 'Rolle and Related Works', p. 27. Also useful is Copeland's 'Richard Rolle and the Rhetorical Theory of the Levels of Style', and Smedick, 'Parallelism and Pointing in Rolle's Rhythmical Style'.

${ }^{73}$ Richard Rolle, Meditations on the Passion, ed. by Allen, p. 19, 11. 7-15. 
The opening of this Passion narrative confronts the reader not with a scene of torture or physical harm, but rather the physical consequences of intense emotion. What is presented is a man shaken to the utmost with fear, a figure at once worthy of reverence and pity. Christ is at once the Man of Sorrows and also Doctor of Souls - his sweat of blood a sign of His own intense fear, and a purgative cure for the diseased soul and body of the reader. The process of sweating has composite medical and theological significations throughout the Middle Ages. It is viewed as both a natural and involuntary purgation of the body, and as an analogy for how confession cleanses the soul through the penitential states it evokes. ${ }^{74}$ Its use here does not simply intertwine ideas of therapy and intense emotion but, when set within Rolle's carefully constructed narrative parallelism, it also works to convey that sense of penitential purgation onto the narrator/reader. We begin not with the Crucifixion but with the prayers in Gethsemane and the fear not of the reader/narrator but of Christ himself. In an interesting and dramatic move, Rolle describes the emotional state of Jesus first and foremost: it is his fear we are confronted with, not our own. Narrative time is confounded here, as expectations of beginning and sequence are not met. This naturally builds suspense, a sense of dramatic tension as the familiar narrative of the Passion is begun in a way that emphasizes the fear and anguish of Christ and, by implication, the pity he is owed. But we must wait for further narrative progress. The events of the Passion are not fired off in rapid succession but lingered over with a careful attention to detail. The reader's foreknowledge of the events of the Passion acts to amplify the current narrative moment. Further emphasis occurs with the way Rolle merges time by mixing past and present tenses: the historical past of Calvary and present moment of reading collapse into one, as the beginning of the meditation and the beginning of the Passion are temporally aligned. This lends an immediacy to the biblical events and a gravity to the meditation, as we become part of a prayerful re-enactment. The three-fold repetition of 'angwysch' -- twice referring to Christ and once referring to the narrator figure - generates a form of affective parallelism, aligning both Christ and the narrative 'I' voice. This connects the reader to Christ with both directness and immediacy, as the repeated articulation of a common feeling creates a sense of commonality.

Vivid detail supplements this move. The passage opens with a direct appeal to one particular sense, an address to Christ that emphasizes his sweetness. This is itself a reference to sapor - that sensorily inflected relish of wisdom - which works to signal that the text will be providing a sapiential account of the Passion. Yet things soon move from taste to sight: his sweetness turns to sweat, specifically drops of blood. Physical properties dominate here but in a thick, sensorially descriptive way. The move from one form of sense data to another is precisely modulated, and this both generates an arresting opening and carries the reader further into the meditation. We hear of Christ's sweetness and his blood sweat, before the narrator — and by extension the reader — asks for 'swete mercy' and to 'swet owt of al sekenesse'. A subtle but potent parallelism is enabled through this careful use of repetition. As Christ is comforted by an angel, so too the narrator/reader asks for one; as Christ sweats blood for anguish, so too the narrator/reader wishes to sweat alongside Him. A sense of alignment is generated, as the reader is positioned by these careful stylistic features into a predetermined posture.

74 Wallis, Medieval Medicine: A Reader, p. 14. See also Hugo de Folieto, De medicina anime, col. 1198: 'Sicut enim in quolibet infirmo aperiuntur carnis pori, ut per sudorem fiat purgatio morbi, sic per confessionem peccati fit laudabilis purgatio animi. Laudatur etiam sudor medicoris si habeatur in omnibus membris. Cum vero sudor a toto manat corpore, omnium membrorum fortitudinem (quod est signum boni) designat. Similiter oportet ut sudor confessionis fiat de peccato cujuslibet operationis' (Indeed as in every sick person the pores of the flesh open so that by means of sweating a purging of the disease shall be made, thus by means of confession of sins commendable purging of the soul should be made). 
The next sections of the text operate in similar ways. Narrative progress occurs as we move into the Trial of Jesus, an account full of vivid and emotionally descriptive detail. We hear much of the "paynes and angwysches and schames and felonyes pat men dyden pe al with tresoun' ${ }^{75}$ As Christ was bound and led away, so too the narrative asks for the reader to be unbound from sins. Further details proliferate - the various shames and insults suffered by Jesus are described, and the mercies shown to Peter emphasized. ${ }^{76}$ An explicit mention of confession is then made that aligns the narrator/reader with Peter ${ }^{77}$ Just as in the preceding lines, we are encouraged to 'repent us of owre trespas and of owre mysdede' through this carefully constructed parallelism. ${ }^{78}$ So far, so descriptive; yet emotionally we are not drawn into compassion directly. We have great detail, some sense of pathos, but not yet burning desire or compassion. This soon changes when the narrative progresses to the scourging where new narrative techniques are employed:

Alas, pat I schal lyve and se my gracious Lord, so soffrenge and so meke, pat nevere trespasyd, so schamely bedyzt! Pe grucchynge and pe gronynge, pe sorwe and pe syschynge, pe rewthe of hys chere I wolde were my deth. ${ }^{79}$

Unlike prior paragraphs, this one deploys a range of devices to express and evoke specific passions. It begins with the interjectional cry of 'alas', an expression, per modum affectus, of sorrow and anguish that operates to set the emotional tone and hue for the rest of the paragraph. The focus shifts from Christ's feelings and anguish to the articulation of those of the narrator and, by extension, the reader. In effect, this is where the meditation begins. The opening interjection has the effect of delimiting all interpretative activity: the first word we hear is a bare articulation that, in terms of its referential range, is an inescapable expression of affect. By beginning with this cry the whole tone of the prose shifts to a more impassioned register. Our attention is seized: we are drawn into the meditation, compelled to feel a certain way by the affective force of the interjection. Yet while the cry expresses and evokes anguish, it is the subsequent lines of the text that work to augment and magnify it. The prose shifts here into a rhythmical patterning similar to the alliterative long-line. ${ }^{80}$ Such a shift functions to structure the passage of narrative time more precisely. Clauses follow each other in a rhythmical pattern that modulates and layers their individual impacts. Events cannot race ahead, but instead proceed within a specifically harmonious temporal sequence that increases their focus and intensity. Through rhythm and meter the opening affective note struck by 'alas' is drawn out and extended throughout the passage. Such regulation of narrative time controls the progress of the reader's interpretative activity, allowing the affective force of the interjection to be held in the mind for as long as possible.

After the opening Rolle uses alliteration and end/medial rhyme. This provides interconnections between the clauses in the passage: 'so soffrenge and so meke' with 'so schamely bedyzt!', and 'pe grucchynge and pe gronynge' with 'be sorwe and pe syschynge'. Alliteration within these units works to bind them together into chains of affective signification. These words do not stand alone but, through their alliterative arrangement, connect with each other to exert composite aural and psychological impacts on the reader that are far greater than each could achieve individually. Interpretative activity is controlled, attenuated via the rhythmical patterning of the passage. The impact of that opening cry is thus extended and refracted through these alliterative pairings. This is also evident from the

${ }^{75}$ Rolle, Meditations on the Passion, ed. by Allen, p. 20, 11. 19-20.

${ }^{76}$ Rolle, Meditations on the Passion, ed. by Allen, p. 20, 11. 28-32.

${ }^{77}$ Rolle, Meditations on the Passion, ed. by Allen, p. 20, 11. 40-2.

${ }^{78}$ Rolle, Meditations on the Passion, ed. by Allen, p. 20, 1. 40.

${ }^{79}$ Rolle, Meditations on the Passion, ed. by Allen, p. 20, 11. 42-6.

${ }^{80}$ Hanna, 'Rolle and Related Works', p. 27. 
passage's paratactic construction. Sentences here are long and detailed, but structured in a way that prevents the narrative from racing ahead. Instead the reader is arrested by the profusion of clauses, each one offering an imagistic flash, an incremental moment of observation heavily saturated by the emotional hue set by the interjection. All interpretative activity is carried out differently via this manner of sentence construction. Due to parataxis the reader must parse the component parts of the passage in a specific way. Each conceptual link in the chain must be held in the mind along with the preceding one, with the result that interpretation becomes spread out in accordance with the rhythmic momentum of the passage. The cumulative effect is one of augmentation. The affective force of that opening cry does not dissipate through a stream of detailed but separate sentences. Instead, the affective impact of the interjection is carried though the rest of the passage by the use of sub-clauses and alliteration. Rolle's stylistic choices ensure that reading becomes slower, with interpretative focus alighting onto those paratactic details in a manner framed by the emotive context of the interjection. Similar processes are at work throughout the text:

A, Lord, pi sorwe, why were it not my deth? Now pei lede pe forthe nakyd os a worm, be turmentoures abowtyn pe, and armede knyztes; pe prees of pe peple was wonderly strong, pei hurled pe and haryed pe so schamefully, pei spurned pe with here feet, os pou hadde been a dogge. ${ }^{81}$

Christ is addressed directly not with calm and cool formalities but with an opening cry of anguish that is itself a rhetorical question. Again, the interjection provides an expression of affect that sets a specific emotional tone for the rest of the paragraph. We get no break in this narrative, it lurches on with an intensive focus on Christ. Rolle uses a shifting perspective to generate an effect of concentration, moving us from a specific focus on Christ as a worm to the vastness of those heaving crowds. ${ }^{82}$ With such contractions come concentration not expansion - emotion does not overflow but, like our attention and the narrative itself, focuses on a point. The familiar narrative of the Passion is thus refreshed and revivified, its central elements augmented by dizzying shifts in perspective and association: the reader is, like Christ, 'haryed' and 'hurled'. This cry of anguish carries over into the next level of detail:

I se in my soule how reufully pou gost: pi body is so blody, so rowed and so bledderyd; pi crowne is so kene, pat sytteth on pi hed; pi heere mevyth with pe wynde, clemyed with pe blood; pi lovely face so wan and so bolnyd with bofetynge and with betynge, with spyttynge, with spowtynge; pe blood ran perewith, pat grysyth in my syðt. ${ }^{83}$

The narrative 'I' voice issues here not to reflect on its own feelings, but to offer a series of highly detailed observations on the Passion. The impact of this long sentence is inescapable, as the buildup of alliterative words and the use of medial/end rhyme slows progress through the narrative. The use of prose rhythm, or cadence, makes it impossible to rush ahead, as each detail comes into focus for a moment all its own. Our interpretative engagement, like our attention, lingers over each sub-clause. The details each contains are thus augmented through narratively prolonged exposure. Their structural interconnection allows these vivid images to become links in a chain, constantly reinforced and reiterated, connected and suffused with an emotive force. There is not one poetic image here but rather several all attached together in a rhythmically determined sequence. This precise interconnection has a specific psychological impact, working to deepen and enrich the affective force of the images. In terms of medieval psychology, each image naturally generates a feeling-toned memory phantasm. Thus, their careful connection here constitutes an affective layering of the image: what each image

${ }^{81}$ Rolle, Meditations on the Passion, ed. by Allen, p. 21, 11. 54-59.

${ }^{82}$ This is also a reference to Psalm 22. 6.

${ }^{83}$ Rolle, Meditations on the Passion, ed. by Allen, p. 21, 11. 59-66. 
depicts is essentially the same, but through this imagistic reiteration and recapitulation the affective impact of the Man of Sorrows is heightened and extended.

The rest of the text looks to other subjects for affective import. Instead of arresting visuals we move to proliferation of sensations. The next section of the text opens with 'A, Lord, pe gronyng pat pou made, so sore and so harde it sat to be bon'. We find here no Stoic Saviour who suffers in silence but a man who groans with pain and misery. ${ }^{84}$ This shift to auditory sense data is a technique of defamiliarization: the reader is prevented from becoming inured to the Passion by being forced to consider new types of sense impression, newly rendered aspects of pain and suffering. The same interjectional cry is present but directed towards the auditory details of the Passion. Successive sentences build upon this framing cry, carefully describing the physical weakness and vulnerability of Jesus and so emphasizing his suffering. We find out how feeble and weary he is, his body already weakened through fasting and lack of sleep. Such detail paradoxically magnifies the work of the Passion by reducing its central figure to a pitiable wretch. Rolle notes that the burden of the cross is 'so sore, pat iche foot pat pou gost it styngyth to pin herte'. ${ }^{85}$ Much like the narrative itself, we too shuffle along with Christ, each step lingering over the vivid details of his pain and humiliation. Slow and halting, the text drags us to its foregone conclusion but with an inescapable emotional energy. Further lines move into new areas and provide speculative detail on the interior subjective state of Christ. This shift is designed to accentuate the affective impact of the passage, providing an extra dimension to the sufferings endured.

A, Lord, pe sorewe pat fele to pi herte, whan pou on pi modur caste pine eyen. Pou saw hyre folewe after among pe gret prees; os a womman owt of hyreselve hyyre handys sche wrong, wepynge and syschynge hyre armys heo caste; pe watur of hyre eyen dropped at hyre feet; heo fel in dede swowne, after pan onys, for sorewe of pe peynes pat to hyre herte smyten. ${ }^{86}$

It is not simply his own pains that make Christ suffer, but also those of his mother. The narrative oscillates between the sufferings of the Virgin and of Christ in a moment of mirrored torment designed to reiterate, reflect, and magnify - a technique of 'wexenge manyfold, with hepynge sorewys' as each recognizes the sufferings of the other. ${ }^{87}$ The shifts in viewpoint allow new details and new textures of the Passion to emerge. These shifts operate by both contrast and similarity: the relative differences between the motionless Christ and the frantic Virgin resolve themselves in pain as, in their agonies, both blur into one. An emotional correspondence develops between them predicated upon the strong contrasts of love and sorrow. ${ }^{88}$ The tender bond between mother and son acts as an affective background that amplifies the pain each is now enduring watching the other suffer: 'as pe love was makeles, so pe sorewe was perelees'. ${ }^{89}$ This connection is reinforced by the repetition of 'eyther for oper': love and sorrow are held together by the narrative in an affective suspension that functions to increase their individual sufferings exponentially. ${ }^{90}$ Ultimately it is pain that connects them, and the narrative focuses on that pain and amplifies it in a way that encourages compassion. Through the narrative's rapid oscillation between Mary and Christ, the reader is led into a simulation of compassion that encompasses both figures. The reader is placed within this reflected pain, within an affective embrace predicated upon emotional correspondences that, due to the narrative, can be shared.

\footnotetext{
${ }^{84}$ Rolle, Meditations on the Passion, ed. by Allen, p. 21, 11. 70-1.

${ }^{85}$ Rolle, Meditations on the Passion, ed. by Allen, p. 21, 11. 78-9.

${ }^{86}$ Rolle, Meditations on the Passion, ed. by Allen, p. 22, 11. 99-105.

${ }^{87}$ Rolle, Meditations on the Passion, ed. by Allen, p. 22, 1. 110.

${ }^{88}$ Rolle, Meditations on the Passion, ed. by Allen, p. 22, 11. 110-14.

${ }^{89}$ Rolle, Meditations on the Passion, ed. by Allen, p. 22, 1. 114.

${ }^{90}$ Rolle, Meditations on the Passion, ed. by Allen, p. 22, 1l. 10912.
} 
Pain is not presented here simplistically, but in a complex layering of physical, personal, and intersubjective torments. It is not just the broken body that acts as the locus of pain, but also that mental pain generated from seeing the pity and compassion of another, that sense of personal anguish for a loved one that heaps sorrow upon sorrow. Yet it all begins with the interjectional cry at the start of the paragraph. That cry strikes an affective note sustained throughout, one that echoes and reverberates over the proceeding lines via the narrative's shifts in perspective and use of repetition, medial/end rhyme, and alliteration. As with preceding passages, the narrative offers the image of the suffering Virgin in a manner that extends and deepens its affective impact. A series of details, essentially imagistic fragments of the same core image, are rapidly presented. The narrative successively focus on her 'hyyre handys', then 'hyre armys', 'hyre eyen', and finally 'hyre feet': visually, the reader is forced to compass her form in its agonies, forced to take in the full physiological and emotional impacts she endures. These fragments are held together via alliteration and the rhythm of the passage - a technique Rolle uses to deepen and prolong the affective impact of each image. The reader is confronted by the suffering Virgin not once but in effect four times: each bodily part constituting a fresh presentation of pain that maximizes the chances of a compassionate response. Pain is the focus, but it is focused on in a manner that includes the reader in its affective embrace:

A, Lady, for pat sorewe pat pou soffryd of pi sonys passyoun - for pat schulde have bein myn owne, for I it hadde deservyd, and manye werse, I was cause pereoffe, and he gylteles, os pe dere woundes were myn owne ryzt - gete, me, for pi mercy, on of hem alle, a prikke at myn herte of pat ilke peyne, a drope of pat rewthe to folewn hym with [...] woundys of reuthe is al my desyr, peyne and compassyoun of my Lord Jhesu Cryst. ${ }^{91}$

Narrative focus rests on the sorrows of the Virgin for only a brief moment; it abruptly shifts perspective mid-sentence, moving not further into the interior state of the central figures of the Passion, but to the inner state of the narrator figure. The narrative 'I' voice breaks through in a sudden profusion of self-reference that functions to personalize the meditation. The abrupt change endows these interpolated reflections of the narrator with an urgency and emphasis. Such a change brings the sufferings and pains described so far into a new narrative locus - that of the narrator figure, and by extension, the reader as well. Exegematic narrative — the form of narrative that uses the 'I' voice — is a technique of re-narration that moves the emotional and affective import of that opening interjectional cry directly onto the reader. It is thus a method not of affective evocation but of affective relocation. ${ }^{92}$ The word 'I' conveys no emotion itself, but instead works as a means of linking into or transposing the affective force inherent in the opening. The ending of this passage, 'I have appetyte to peyne, to beseke my Lorde a droppe of hys reed blod to make blody my soule', operates in just this way, relocating suffering and pain onto the merged narrator/reader. ${ }^{93}$ It is a technique repeated by Rolle throughout the rest of the text. The next lines' 'herken to pis wrecche, and vysyt thy chyld. Soue in myn herte, pat is a hard os ston, a sparcle of compassyoun', is referentially ambiguous. ${ }^{94}$ The designation 'thy chyld' can refer to both Christ and the narrator, and thus functions to merge and align their respective positions. This process of affective realignment reaches its climax with Rolle's careful use of lyric in the next two passages:

${ }^{91}$ Rolle, Meditations on the Passion, ed. by Allen, p. 23, 11. 131-46.

92 Spearing has recently argued that this narrative technique is a form of 'deixis' - a textual way of encoding relationships. The 'I' does not convey meaning in and of itself, but rather creates 'spatiotemporal relation and thus by extension [...] epistemic and emotional relations' (Spearing, Medieval Autographies, pp. 910).

${ }^{93}$ Rolle, Meditations on the Passion, ed. by Allen, p. 23, 11. 149-50.

${ }^{94}$ Rolle, Meditations on the Passion, ed. by Allen, p. 24, 11. 154-55. 
Gloryouse Lord, so doolfully dyzte,

So rewfully streynyd upryðt on pe cros:

For pi mykel mekenesse, pi mercy, pi myzt,

Pou bete al my bale with bote of pi blood. ${ }^{95}$

That word 'bote' has a dual theological and medical significance, meaning both deliverance and remedy. ${ }^{96}$ This small verse occurs immediately after the text's Crucifixion scene, and as such performs the crucial function of providing intensification and focus. ${ }^{97}$ The actual crucifixion is presented in the preceding passage in a profusion of descriptive detail. We hear tell of 'stronge ropys'; of nails 'blonte at pe poynt'; of the instruments of torture that 'schulde breste be skyn and pe flesch'; of detail designed to paint a scene of 'more peyne'. ${ }^{98}$ This lyric, however, is not visually evocative: Christ's blood and the Cross are the only concrete things referred to. Consequently, the function of the lyric is not to provide supplementary detail to the passage, but rather to intensify its effect. Indeed, Rolle displays a sophisticated tactical awareness of the potential uses of lyric in his prose works, inserting lyrical passages at key moments to provide 'meditative paradigms appropriate to the level of advancement under discussion'. ${ }^{99}$ This lyric, written in alliterative long-line, operates in much the same way. It does not have a fast rhythm nor does it proceed rapidly: the use of alliteration - especially the series of plosives in the last line - and end rhyme work here to slow down and stagger the verse. Rolle's move to a more structured poetic form is also a deliberate choice to move the reader into a more structured passage of time. The lyric's purpose is to slow things down. Its pace is slowing, as its use of alliteration and its meter work to make us linger over the Passion. We cannot pass quickly over the gruesome moment of crucifixion, but must slowly move through it. The lyrical form exerts much more control over the reader, not only affording more precisely delineated interconnections between concepts such as 'dyzte' and 'myzt', but also regulating breath as well. Inspiration, like ideation, is corralled and controlled, focused and directed through the repetition of the words.

The move to lyric is itself a more intimate poetic mode, one that makes the Passion as personal as possible. Lyric also works to extend that moment of the Passion, to focus our affective response to it. The affective force of the opening of the preceding passage - that interjectional cry of 'A, Lord' - is amplified, as it echoes that cry with its own focus on 'doolfully', 'rewfully', and 'bale'. These words provide a form of epiphora here - a way or repeating or mirroring the interjection at the beginning, but drawing it out further in a series of words designed to specify and augment that initial cry of anguish. In this way, the moment of the Passion is both affectively and effectively shared. Its meter and alliteration not only generate a shared sense of time, but also resonate with the details of Christ's pain and suffering. The very next sentence, which lasts for several lines, carries this forward. It begins with the cry 'A, Lord, pi pyte pat I now se: wounds in pi streynynge reche so wyde', but from here on in the narrative 'I' voice dominates the perspective. ${ }^{100}$ No longer do we see things from the point of view of Christ or the Virgin. It is the narrator figure that sees and feels, and who notes that 'pi woundys are for-bled and grysly on to se' and that 'be sorewe pat pi modur makyth encresuth pi woo'. ${ }^{101}$ This constitutes and concludes the most affective section of the

${ }^{95}$ Rolle, Meditations on the Passion, ed. by Allen, p. 24, 11. 169-72.

${ }^{96} \mathrm{MED}=$ Middle English Dictionary <http://quod.lib.umich.edu/m/med/> accessed October 2013. 'Bote': http://quod.lib.umich.edu/cgi/m/mec/med-idx?type=id\&id=MED5609.

97 The lyric is not Rolle's own, but taken from another source. See Allen's endnotes (pp. 131-32) for further details.

${ }^{98}$ Rolle, Meditations on the Passion, ed. by Allen, p. 24, 1l. 160, 165, 165-66, 167.

${ }^{99}$ Gillespie, 'Mystic's Foot: Rolle and Affectivity', p. 223.

${ }^{100}$ Rolle, Meditations on the Passion, ed. by Allen, p. 24, 11. 173-74.

${ }^{101}$ Rolle, Meditations on the Passion, ed. by Allen, p. 24, 1l. 181, 182. 
text, as Rolle has been concerned with evoking pity and compassion from the reader up to this point.

An extended lyric follows that makes extensive use of the 'I' voice, but that moves from the Passion to the narrator's own prayer for compassion. The use of interjections stops after this sequence, with sentences beginning without exclamation. We move from Christ's anguish to an anguished prayer for compassion — an emotional state the narrator finds extremely difficult. This is perhaps Rolle's most rhetorically sophisticated move, a way of demonstrating the importance of true affect preceding true prayer. The text has performed its function: it has stirred up those strong passions which precede true prayer to God and enable the purgation of the soul. We have in effect come full circle, as those initial cries to God now beget the narrator's own cry of prayer and the coming of the 'heavenelyche leche' who will provide a therapeutic bath of blood and vivify the dead heart of the narrator. ${ }^{102}$ Rolle's carefully crafted words have been medicinal, have moved even the hardest of hearts (here the narrator's) into a state 'souple and softe in pi grace', by evoking those cathartic passions of penance and pity. The medicine of words, therefore, does not stop at evoking the passions so as to purge; rather it compels us to action, moving us towards our own cries of prayer. As Rolle notes in his Psalter commentary:

I sall cry til god heghest: til god that wele did til me. I sall not be ydell, bot I sall cry with all the myght of my hert til god highest, forthi me bihoues nede cry. Bot I hafe proued his goednes, for he did wele til me, that he herd me criand. ${ }^{103}$

Rolle's medicine of words consists not simply of the impact of those words upon the soul, but also of the cries of prayer that these same therapeutic words compel us to make. For Rolle, poetry has the power to combine purgation with praise, rhythm with reality - to move and medicate us in mysterious ways.

${ }^{102}$ Rolle, Meditations on the Passion, ed. by Allen, p. 27. 11. 266, 271, 269.

${ }^{103}$ Rolle, Psalter, ed. by Bramley, Ps. 55, p. 202. 


\section{Works Cited}

\section{Primary Sources}

Augustine, Sermo XXXII: In Psalmum CXLII. De Golia et David ac de contemptu mundi, in Patrologia cursus completus series latina, 38, ed. by Jacques-Paul Migne and others (Paris: Migne, 1863).

— St Augustine: Expositions on the Psalms, ed. by Philip Schaff, trans. by J. E. Tweed in Nicene and Post-Nicene Fathers, 1st ser., 8 (repr. New York: Cosimo, 2007).

Albertus Magnus, Super Mattheum, in Alberti Magni Opera Omnia: Cura et studio Instituti Alberti Magni, vol. XXI, ed. by Bernardus Schmidt (Münster: Aschendorff, 1987).

Brown, Carleton, ed., Religious Lyrics of the Fourteenth Century, 2nd edn (Oxford: Clarendon Press, 1956).

Cassiodorus, Cassiodorus: Explanation of the Psalms, vol.1, trans. by P. G. Walsh (New York: Paulist, 1991).

Celsus, De Medicina, ed. and trans. by W. G. Spencer (Cambridge, MA: Harvard University Press, 1956).

Donatus, Ars Minor, in Medieval Grammar and Rhetoric: Language Arts and Literary Theory, AD 300-1475, ed. and trans. by Rita Copeland and Ineke Sluiter (Oxford: Oxford University Press, 2009).

Guy de Cauliac, The Cyrurgie of de Chauliac, Volume One, ed. by Margaret S. Ogden, Early English Text Society, o.s., 265 (London: Oxford University Press, 1971).

—, The Middle English Translation of Guy de Chauliac's Anatomy, ed. by Björn Wallner (Lund: Gleerup, 1964).

Horstmann, Carl, ed., Yorkshire Writers: Richard Rolle of Hampole, an English Father of the Church, and his Followers, vol. 2 (London: Sonnenschein, 1896).

Hudson, Anne, ed., Two Revisions of Rolle's English Psalter Commentary and the Related Canticles, Vol. 1, Early English Text Society, o.s., 341 (Oxford: Oxford University Press, 2012).

Hugh of St Victor, 'Le De grammatica de Hugues de Saint Victor', in Archives d'histoire doctrinale et littéraire du moyen âge, 20, ed. by Jean Leclercq (Paris: Vrin, 1945), p. 288. lines 23-6.

Hugo de Folieto, De medicina anime, in Patrologia cursus completus series latina, 176, ed. by Jacques-Paul Migne (Paris: Vrin, 1854).

John of Garland, The Parisiana Poetria of John of Garland, ed. and trans. by Traugott Lawler (Yale: Yale University Press, 1974).

Lanfrank, Science of Cirurgie, ed. by Robert Von Fleischhacker, Early English Text Society, o.s., 102 (London: Kegan Paul, Trench, Trübner, 1894).

Langland, William, The Vision of Piers Plowman: A Critical Edition of the B-Text Based on Trinity College Cambridge MS B.15.17, ed. by A.C.V Schmidt, 2nd edn (London: Everyman, 1995).

Richard Rolle, English Writings of Richard Rolle, Hermit of Hampole, ed. by Hope Emily Allen (Oxford: Clarendon Press, 1931).

Richard Rolle, Prose and Verse, Edited from MS Longleat 29 and Related Manuscripts, ed. by S. J. Ogilvie-Thomson, Early English Text Society, o.s., 293 (Oxford: Oxford University Press, 1988). 
_ _ _. Uncollected Prose and Verse with Related Northern Texts, ed. by Ralph Hanna III, Early English Text Society, o.s., 329 (Oxford: Oxford University Press, 2007).

_ _ - . The Psalter of the Psalms of David and Certain Canticles With a Translation and Exposition in English, ed. by H. R. Bramley (Oxford, Clarendon Press, 1884).

Roger Bacon, Communia Naturalium, in Opera Hactenus Inedita Volume 2, ed. by Robert Steele (Oxford: Oxford University Press, 1905).

Thomas Aquinas, De Malo Quaestiones disputatae de malo, in Sancti Thomae de Aquino Opera Omnia Editio Leonina, vol. 23 (Rome: Commissio Leonina, 1982).

\section{Secondary Studies}

Alford, John, 'The Grammatical Metaphor: A Survey of its Use in the Middle Ages', Speculum, 57 (1982), 728-60.

_ ' 'Rolle's English Psalter and Lectio Divina', Bulletin of the John Rylands Library, 77 (1995), 47-59.

Arbesmann, Rudolph, 'The Concept of "Christus Medicus ” in St. Augustine', Traditio, 10 (1954), 128.

Carruthers, Mary, The Book of Memory: A Study of Memory in Medieval Culture (Cambridge: Cambridge University Press, 1990).

—, The Experience of Beauty in the Middle Ages (Oxford: Oxford University Press, 2013).

Cohen-Hanegbi, Na'ama, 'Accidents of the Soul: Physicians and Confessors on the Conception and Treatment of Emotions in Italy and Spain, Late 12th-15th Centuries' (unpublished doctoral thesis, Hebrew University, 2011).

Copeland, Rita, 'Richard Rolle and the Rhetorical Theory of the Levels of Style', in The Medieval Mystical Tradition in England, Volume Three, 8 vols., ed. by Marion Glasscoe (Exeter: Exeter University Press, 1984) pp. 55-80.

Gellrich, Jesse, The Idea of The Book in The Middle Ages: Language Theory, Mythology, and Fiction (Ithaca: Cornell University Press, 1985).

Gillespie, Vincent, 'From the Twelfth Century to c. 1450', in The Cambridge History of Literary Criticism, vol. II: The Middle Ages, ed. by Alastair Minnis and Ian Johnson (Cambridge: Cambridge University Press, 2005) pp. 145-236.

- 'Mystic's Foot: Rolle and Affectivity', in The Medieval Mystical Tradition in England, Volume Two, 8 vols., ed. by Marion Glasscoe (Exeter: Exeter University Press, 1982) pp. 199-230.

- 'The Senses in Literature: The Textures of Perception', in A Cultural History of the Senses in the Middle Ages, ed. by Richard G. Newhauser (London: Bloomsbury, 2014), pp. 153-73.

— , 'The Songs of the Threshold: Enargeia and the Psalter', in The Psalms in Medieval English Literature, ed. by Tamara Atkin and Francis Leneghan (Woodbridge: Brewer, forthcoming).

Hanna, Ralph, 'Rolle and Related Works', in Middle English Prose: A Critical Guide to Major Authors and Genres, ed. by A. S. G. Edwards (New Jersey: Rutgers University Press, 1984).

Horden, Peregrine, 'Religion as Medicine: Music in Medieval Hospitals', in Religion and Medicine in the Middle Ages, ed. by Peter Biller and Joseph Ziegler (York: Boydell and Brewer, 2001), pp. 135-54.

Kelly, Louis. G., The Mirror of Grammar: Theology, Philosophy, and the 'Modistae', Amsterdam Studies in the Theory and History of Linguistic Science, 3/101 (Amsterdam: Benjamins, 2002). 
Leclercq, Jean, The Love of Learning and the Desire for God: A Study of Monastic Culture, trans. by Catharine Misrahi (New York: Fordham University Press, 1961).

Madigan, Mary Felicitas, The Passio Domini Theme in the Works of Richard Rolle: His Personal Contribution in its Religious, Cultural, and Literary Context, Elizabethan and Renaissance Studies, 79 (Salzburg: Institut für englische Sprache, 1978).

Mooney, Linne, 'Scribes and Booklets of Trinity College, Cambridge, MSS R.3.19 and R.3.20', in Middle English Poetry: Texts and Traditions: Essays in Honour of Derek Pearsall, ed. by Alastair Minnis (York: Boydell and Brewer, 2001), pp. 241-66.

Morgan, Margery M., 'Versions of The Meditations on the Passion Ascribed to Richard Rolle', Medium Aevum, 22 (1953), 93-103.

Olson, Glending, Literature as Recreation in the Later Middle Ages (Ithaca: Cornell University Press, 1985).

— - 'The Profits of Pleasure', in The Cambridge History of Literary Criticism, vol. II: The Middle Ages, ed. by Alastair Minnis and Ian Johnson (Cambridge: Cambridge University Press, 2005), pp. 275-90.

Reid, Shelley Annette, 'The First Dispensation of Christ Is Medicinal: Augustine and Roman Medical Culture' (unpublished doctoral dissertation, University of British Columbia, 2008).

Rosier-Catach, Irène, 'Roger Bacon: Grammar', in Roger Bacon and the Sciences: Commemorative Essays, ed. by Jeremiah Hackett (Leiden: Brill, 1997) pp. 67-102.

Smedick, L. K., 'Parallelism and Pointing in Rolle's Rhythmical Style', Mediaeval Studies, 41 (1979), pp. 404-67.

Spearing, A. C., Medieval Autographies: The 'I' of the Text. Conway Lectures in Medieval Studies 2008 (Notre Dame: Notre Dame University Press, 2012).

Stock, Brian, 'Healing Meditation, and the History of Reading', New Literary History, 37 (2006), 503-13.

—_, 'Minds, Bodies, Readers', New Literary History, 37 (2006), 489-501.

Wallis, Faith, ed., Medieval Medicine: A Reader (Toronto: Toronto University Press, 2010).

White, Victor, Holy Teaching: The Idea of Theology According to St Thomas Aquinas (London: Blackfriars Publications, 1958) 